IRA-International Journal of Management \& Social Sciences

ISSN 2455-2267; Vol.06, Issue 01 (2017)

Pg. no. $85-90$

Institute of Research Advances

http://research-advances.org/index.php/RAJMSS

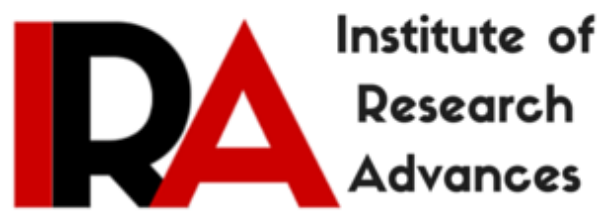

\title{
Strategic Green HRM - The Integration of Environmental Management into HRM with reference to one of the Healthcare Industry
}

Shikha Yadav

Assistant Professor, NHC

Bangalore, Karnataka, India.

Type of Review: Peer Reviewed.

DOI: http://dx.doi.org/10.21013/jmss.v6.n1.p11

How to cite this paper:
Yadav, S. (2017). Strategic Green HRM - The Integration of Environmental
Management into HRM with reference to one of the Healthcare Industry. IRA-
International Journal of Management \& Social Sciences (ISSN 2455-2267), 6(1), 85-90.
doi:http://dx.doi.org/10.21013/jmss.v6.n1.p11

(C) Institute of Research Advances

(cc) EY-NC

This work is licensed under a Creative Commons Attribution-Non Commercial 4.0 International License subject to proper citation to the publication source of the work.

Disclaimer: The scholarly papers as reviewed and published by the Institute of Research Advances (IRA) are the views and opinions of their respective authors and are not the views or opinions of the IRA. The IRA disclaims of any harm or loss caused due to the published content to any party. 


\begin{abstract}
This paper studies one of the healthcare industry of India "Sun Pharmaceutical Industries Limited" which is ranked at 352 amongst the world's largest 500 companies on corporate sustainability and environmental impact according to Newsweek in 2016. Sun Pharmaceutical Industries limited is the only company in the healthcare sector in India which has been listed as one of the Green companies in India. This paper mainly focuses on understanding and analysing the Green initiatives as a part of Corporate social responsibility (CSR) taken by the company which makes it the green company in India in Healthcare sector.

The green scores of the company has also increased by 4\% compared to the previous year (2015), which shows that the company is always striving to incorporate strategic Green HRM. Strategic Green HRM is one of the growing innovative approaches which promotes the sustainable use of resources of the business organisation and thus integrates environmental management into HRM.
\end{abstract}

Key words: Strategic Green HRM, Environment Sustainability, Resource Conservation, Corporate Social Responsibility (CSR), Environmental Management

\title{
Introduction
}

In today's world companies are putting lot of efforts for implementing Environmental Management System which act as a tool to gain competitive advantage and helps in controlling the firm's environmental impacts. Nowadays companies which are adopting to Strategic Green HRM practices are able to attract and retain good employees which further helps in reducing the replacement cost. Strategic Green HRM policies encourage sustainable use of resources in an organisation in order to promote the cause of environmentalism and hence develop employee moral and satisfaction. It is been observed that there is a growing need for practicing strategic green HRM that is integrating environmental management into HRM. It has now become very important to encourage employees to be more environmentally friendly while working in the organisation.

\section{Methodology}

The study is primarily based upon the secondary data. For this extant literature related to the topic from different databases, websites and other available sources were collected. A systematic review of collected literature was done in detail.

\section{Theoretical Background}

\section{Strategic Human Resource Management}

Strategy is a pattern or plan of action which are set in advance to achieve organisation goals and objectives by relating the resources of the organisation with its environment.

Nowadays organisations try to formulate strategies keeping in mind the human resources aspects and based on these strategies the human resources are managed in an organisation. The main aim of practicing SHRM in the organisation is to make sure that HR policies are well aligned with the strategies of the organisation meant to achieve the organisation goals and objectives.

\section{Green HRM}

There is a growing concern over global warming and the major threat is from the industrial pollutants and carbon emissions which is very harmful for the environment leads to eco imbalance. Environment sustainability should be the top priority of every organisation and for this they implement corporate social responsibility (CSR) which also helps them to improve their image and brand in society and market. Therefor, it is important for the organisation not only invests in CSR activities but also inculcate green sense of responsibility in the employees. Taking initiative and implementing HRM policies which create green sense of responsibility is what highlights importance of practicing green HRM in the organisation.

The various functions of HR where we can apply green HRM strategies are as follows: 


\section{Recruitment and Selection Process}

Use of technology in the organisation like database management system, internet can be very helpful in reducing the wastage of resources. Nowadays companies look upto different websites for hiring people which reduces the resume printing and courier cost and also leads to less usage of paper. Various information related to companies like their rules, policies, objectives, records are all published on company's websites which helps in less cost to be incurred on printing brochures, rule books, and pamphlets etc. Most importantly, preference should be given to candidates who are green aware which should become a part of recruitment policy.

\section{Performance Appraisals}

When it comes to appraising the employees of the organisation it is important to consider the Green initiates, green targets, objectives and accountabilities taken up by the employees and recognising the accomplishments and completion of green results.

Thus performance management system should also include Green targets as one of the key performance area of the employee. Green contributions of employees can be honoured through advertising and appreciation of green efforts by top managers.

\section{Orientation}

With the help of technology like projectors and laptops training can be provided to the employees. It is also important for employees to understand their sense of responsibility towards the environment and how the organisation with the help of employees support can achieve environment sustainability. And orientation program related to Green HRM would be very helpful in that aspect.

\section{TRAINING AND DEVELOPMENT}

It is important for an organisation to impart training to employees and inform them about the green policies, practices and procedures. It is also required that employees should be made aware about how green initiative like creating green products and reducing green house gases, can build companies image and accomplish vision \& mission and highlight company's sustainability oriented benefits. There are various companies in US which provides training on regulatory requirement and Environmental Quality Management.

\section{EMPLOYMENT RELATIONS}

Employee's involvement and participation is what we refer to as employee relations. An organisation can successfully make employees accept its green policies when it involves employees in designing these policies. Who understand better than an employee about his work, so he would be the right person to think how he can do his job by cutting down cost and reducing wastage of resources. When an employee is encouraged more for participating than it boost their morale and make them feel committed towards their organisation. Employees should be encouraged to form quality circle which would completely focus on developing strategies, policies and procedure regarding green HRM and how employees can be driven towards achieving organisational sustainability.

\section{Case study: Sun Pharmaceutical industries limited}

By limiting the definition of growth to just economic development, mankind is ironically progressing towards a time where basic needs like clean air, fresh water, rich biodiversity and required natural resources are getting scarce. Sun Pharma is one of the company which is always vigilant of the emerging situation and investing in measures that convert these challenges into opportunities. Be it conservation measures or reducing our dependence on limited resources, Sun Pharma is not only reducing the burden on the environment, but also on their operational costs

At Sun Pharma, a robust Environment, Health \& Safety (EHS) policy is in place which encourages employees to be more ecologically aware and makes the vigilant teams to be more cautious in preempting potential threats by developing relevant measures to address them.

Mentioned below are some of the green dos at Sun Pharmaceutical Industries limited:

1. Ensure statutory compliance

2. Optimise natural resources 
3. Effect continuous improvement in environment management

4. Innovate greener technologies and processes

5. Spread green awareness across internal and external stakeholders

6. Waste Management: Effective waste management is accomplished at Sun Pharma through a host of well-laid-out and continuously- monitored procedures.

4Rs in Action:

i. $\quad$ Reduce the production of waste by minimising waste at source.

ii. Recycle waste materials including solvents, wastewater, glass, plastic liners, HDPE sheets and waste oil.

iii. Initiatives consist of set-up of effluent treatment plants, recycling through registered recyclers and engaging scrap vendors for materials like paper, plastic and HDPE

iv. Many of the units are Zero Liquid Discharge (ZLD) facilities and the remaining ones are in the process of obtaining the status.

v. Reuse the recovered solvents as and when possible, enabled by well-equipped solvent recovery systems.

vi. Responsible disposal - ensure safe and responsible waste disposal at Government approved sites.

7. Energy Conservation: Sun Pharma is leveraging all available alternatives to conserve as much energy as possible. These options broadly can be classified into two categories - tapping technology to generate green energy and using energy efficiently in manufacturing processes.

8. Green Investments: Sun Pharma has invested significantly in green energy, principal amongst which is investment in wind energy. One of the facilities is dedicated towards harnessing the power of wind to generate energy. In FY16, Sun Pharma generated around 1,145,560 kWh of clean energy.

9. Greener Operations: Sun Pharma also undertakes a host of initiatives to usher in energy efficiency via process efficiency. Some of such interventions implemented across various units to further optimise the systems in the financial year include:

i. Installation of boiler economisers and air pre-heaters Using condensate recovery pumps

ii. Use of fuel-efficient packaged boilers that use heat from waste gases of engine exhaust

iii. Steam generation from exhaust gas and hot water generation from jacket heat

iv. Installation of Variable Frequency Drives (VFDs) to save energy at all AHUs

v. Use of energy efficient screw chillers and rotary air compressor with VFD

vi. Recovery of gas super heater to make hot water Generating steam from waste heat of the captive power plant

vii. Installation of motion sensors to reduce electricity wastage Replacement of CFL and metal halide lamps with LED Lights

viii. Energy efficient planetary gear box installation in manufacturing plant for reactors

10. Carbon Emission: Sun Pharma has implemented a Clean Development Mechanism (CDM) project at their facilities by switching from 'conventional' furnace oil / light diesel oil boilers to 'eco- efficient' biomass briquette-based boilers. Along with restricting the emissions of their operations, it will achieve two more purposes:

i. Social well-being: It will generate additional income opportunities for the local population

ii. Environmental well-being: It will replace fossil fuels by a carbon-neutral fuel

11. Employee Wellness: Sun Pharma's most valuable asset is their multi-cultural team. With a strength of 30,000+ employees, the have invested in their energy in engaging, nurturing and motivating them to grow. In FY16, they increased their investments in training and development of workforce. They are also inculcating in their team, the value of responsible growth. This ensures that each one of them serves the community and protects the environment, while performing their roles.

12. Environment Wellness: At Sun Pharma, an all-inclusive EHS (Environment, Health and Safety) policy is in place to ensure a safe environment in the workplace and a better environment in the world. Technology-based differentiations in their energy efficiency 
initiatives rival those in their products. In FY16, 1.15 million kWh of green energy was generated. 'Zero Liquid Discharge' is the norm in many of their plants, while the remaining plants are leading towards it.

\section{Result \& Discussion}

This paper helps in getting an insight into how a company can work efficiently by taking care of the environment. It is seen that a company by implementing strategic Green HRM, not only improves its image across the world but also reduces it operation cost. Organisations need to focus on encouraging employees to adopt to new green ideas follow organisation's Green policies, procedures and plans. Organisation should take green initiatives like discouraging the use of paper in filing by doing efiling, pooling cars for commuting, using sunlight during day time by adopting green architecture in building their office, conducting tree plantation camps, providing work from facilities to employees, conduct annual Going Green or Sustainable Organization survey, do teleconference to reduce business travel, monitor sinks and toilets for leaks that waste water. Successful implementation of Green HRM is possible when an organisation rewards and honours the employees, provide proper training and development to the employees, better employee relations. Thus organisations are focusing on integrating Green HRM with the environment management with the help of Strategic HRM

\section{Corporate Environmental Citizenship}

Environmental Citizenship is a new concept which defines that how we all are an integral part of a larger ecosystem and in order to protect our future we need to accept the challenges and act responsibly and ethically towards our environment. We need to make changes in our day to day life to be environmental citizens.

As discussed above, all the Human resource management practices like training and development, performance appraisal, recruitment and selection \& employee relations helps in promoting corporate environmental citizenship. In the context of this study, it is important for companies to integrate human resource practices with environment management inorder to enhance environmental friendly behaviour and corporate environmental citizenship For example, as specified under recruitment and selection, if an organisation includes environmental awareness as one of the criteria than the employees would be able to communicate with other employees regarding green environment, share their environmental skills and conduct environmental training which can improve employees' environmental friendly behavior and corporate environmental citizenship.

\section{Conclusion}

Nowadays companies are becoming more aware about their responsibilities towards environment and thus they are more involved in motivating and encouraging their employees to develop a sense of responsibility towards better utilisation of resources and maintain environment sustainability. By doing so companies are not only reducing their dependence on scarce resources and easing the pressure on the planet but also improving their operational cost. The limitation of this paper is that it covers only one company from healthcare sector Further research studies can be done on other sectors and industries to gain a wider insight and impact.

\section{References:}

[1] Sun Pharmaceuticals Industries Ltd Business Responsibility report 2015-16

http://www.sunpharma.com/download.php?download_file=Sun\%20Pharma\%20BRR.pdf

[2] Sun Pharmaceuticals Industries Ltd Annual report 2015-16

https://www.sunpharma.com/sites/default/files/annual/SPIL\%2024th\%20Annual\%20Report\%202015 -16.pdf

[3] Gaurav Jain : "Business Ethics \& the Environment : Evolution of Green HRM"

https://www.linkedin.com/pulse/business-ethics-environment-evolution-green-hrm-gaurav-jainn 
[4] Dr. Parul Deshwal (2015), Green HRM : An organisational strategy of greening people, International Journal of Applied Research, Vol.1, No. 13

[5] Newsweek 'TOP GREEN COMPANIES IN THE WORLD 2016'

http://www.newsweek.com/green-2016/top-green-companies-world-2016

[6] A. Anton Arulrajah, Prof. H.H.D.N.P. Opatha, Dr. N.N.J. Nawaratne (2015), Green Human Resource Management Practices: A Review, Sri Lankan Journal of Human Resource Management, Vol. 5, No. 1

[7] Suhaimi Sudin (2011), Strategic Green HRM: A Proposed Model that supports corporate environmental citizenship, Internal conference on sociality and economics development, IPEDR, Vol. 10

[8] Dr. Apoorva Trivedi (2015), Strategic Green HRM: A necessity of $21^{\text {st }}$ Century, International Journal of Business Quantitative Economics and Applied Management Research, Vol. 2, Issue 2

[9] Dr. K Mishra, Sushma Rani (2014), Green HRM: Practices and Strategies Implementation in the organisations, International Journal on Recent and Innovation Trends in Computing and Communication, Vol. 2, Issue 11. 